\title{
Overview of Students' Physical Fitness in Padang
}

\author{
Nirwandi*, Ahmad Hasan, I Wulandari \\ Sport Education Program \\ Faculty of Sport Science \\ Padang State University \\ Padang, Indonesia \\ nirwandi@fik.unp.ac.id
}

\begin{abstract}
The purpose of this research is to know how the physical fitness level of students in SD N 44 Kalumbuk Padang. The research is a descriptive study, which describes the result of the analysis by looking at the percentage and category ratings. The population in this study were students in SD N 44 Kalumbuk Padang. The sampling technique is random sampling, using the research instrument measuring instrument Tests Physical Freshness Indonesia (TKJI). Data were analyzed using descriptive analysis by calculating the percentage of votes. Based on the results of research in data analysis, 1) Students Putra SD N 44 Kalumbuk Padang is in the category enough. 2) Students Physical Freshness Princess SD $\mathbf{N} 44$ Kalumbuk Padang is in the category enough.
\end{abstract}

Keywords — Level of Physical Freshness

\section{INTRODUCTION}

Physical fitness is the ability to make adjustments (adaptation) to physical exemption granted to him [1]. Physical fitness is the ability to perform activities or daily work and adaptation to physical pernbebanan without causing excessive fatigue and still have a reserve energy to enjoy leisure time and work suddenly and free of disease [2], Penjasorkes in school is one of the fields of study that should be followed by all students. This field of study can develop aspects or potential that is more straightforward when compared with other fields of study. Penjasorkes not only to develop the components of thinking and the ability of mental attitude [3]. Judging from the level of education in elementary penjasorkes a basic capacity development to support the attitude, behavior and health that are tailored to the circumstances and needs of the environment.

The purpose of physical education and health one of which assist students in improving health and fitness through the introduction of cultivation of positive attitudes and health and basic motor skills of a variety of physical activities [4]. With this purpose more visible that physical fitness is an important aspect in the face of an activity. Physical fitness is needed by students to gain agility, ability and a high learning ability. Physical fitness level will assist in carrying out a daily work without causing significant fatigue. One way to maintain or improve physical fitness is to exercise the right and daily physical activity is beneficial for health. Because health is determining a person's activity.
Based on the results obervsi and interview researchers At the student's Fourth Grade Elementary School 44 Kalumbuk Padang found that low levels of physical fitness be seen from the first, Conducting tests Physical Freshness include: Sprint, tests hanging elbow bend, Baring sit down, jump up, run 600 meter. At the time of the test many students who get low grades. Low levels of physical fitness caused by the lack of nutritional knowledge, economic level, family members factors, environmental factors, the availability of food, physical activity habits of students, facilities and infrastructure is lacking, the physical condition of the students.

According [5] physical fitness test used for children of primary school age 10-12 years of age include: 40 meter sprint test, Hanging elbow bend, Baring sitting, Skip upright, running 600 meters. Physical fitness is the ability to carry out everyday tasks diligently and with full alertness, without experiencing significant fatigue, and with enough energy to enjoy leisure time and face things unforeseen emergency. physical fitness is required by each individual is very different and varied, depending on the nature of the physical challenges that face it, for example seoarang athletes physical fitness is different compared to the clerks.

\section{METHODS}

Type of research is descriptive. The population in this study were students of SDN 44 Kalumbuk Padang, amounting to 207 people, consisting of 104 male students and 103 female students of Women. In this study, using simple random sampling. Understanding simple random sampling is a sampling technique of members of the sample of the population was randomly without regard to strata that exist in the population. Samples are fourth grade students of SDN 44 Kalumbuk Padang numbering 36 members, namely 17 sons and 19 daughters.

Data collection techniques used in the research is determined by the level of physical fitness, physical fitness tests that have been agreed and confirmed a test tool that applies throughout the territory of Indonesia for TKJI prepared according to the conditions of Indonesian children. Processing data on physical fitness level of Class IV students of SD Negeri 44 Kalumbuk Padang done through a descriptive analysis of the percentage. 


\section{RESULTS}

According to data collected from 17 sample that represents the male student obtained the spread of answers based on the level of classification as follows, classified as "Very Good" frequency $=0 \%$, "Good" frekuens $=2$ $(11.76 \%)$, "Medium" frequency $=10(58.82 \%)$, "Less" frequency $=5(29.41 \%)$, and "Less Once" frequency $=0 \%$.

According to data collected from 19 sample representing the female student obtained the spread of answers based on the level of classification as follows, classified as "Very Good" frequency $=0 \%$, "Good" frekuens $=4(21: 05 \%)$, "Medium" frequency = $12(63.16 \%)$, "Less" frequency $=3$ $(15.79 \%)$, and "Less Once" frequency $=0(0 \%)$.

According to the table above can be explained that the physical fitness level of boys and girls fourth grade SDN 44 Kalumbuk City Padangdapat grouped in five categories: students who are included in the category of "Well" frequency $=0(0 \%)$, "Good" frequency $=6(16.67 \%)$, "Medium" frequency = $22(61.11 \%)$, "Less" frequency $=8$ $(22: 22 \%)$, and "Less Once" frequency $=0(0.00)$

\section{DISCUSSION}

One's learning process will be interrupted if the person's health, especially their physical fitness will be disrupted and it will be fatigue, lack of drive, easy dizziness, drowsiness if he was very weak, less blood or no disturbances in the function of the sensory organs in the body. Given the importance of physical fitness for someone, it is important to improve physical fitness is a physical activity and exercise regularly, the body requires oxygen to produce energy for the body does not store oxygen. Oxygen should be taken and distributed to all organs and tissues of the body that require energy. The ability of the body to do it depends on the physical fitness level of each individual.

For people who have a good level of physical fitness would be easy to do the uptake of oxygen needed by the body. And for people who are low physical fitness level, this is a difficulty, which means, in other words for those who do a lot of physical activity and exercise regularly then their physical fitness level improved compared with the less physical activity and exercise regularly.

It can be concluded that physical fitness is the aspect of physical capability that support the success of students in various activities in daily life without causing fatigue berarti.Dan it is important to improve physical fitness is exercise and regular exercise, the body needs oxygen to produce energy, the body does not store oksigen.Oksigen be taken and distributed keorgan of organs and tissues that need energi.Kemampuan body to do it depends on the physical fitness level of each individual. For people who have a good level of physical fitness would be easy to do the uptake of oxygen needed by the body. For people who are low physical fitness level,

From the results of the descriptive analysis of the data reveal that of the 36 samples of Class IV students of SD Negeri 44 Padang portrait Kalumbuk physical fitness level
"Medium" on a male student, and "Medium" on a female student. Of the 17 sample representing the male students, the obtained spread of answers based on the level of classification as follows, klasifikakasi "Less than Once" frequency $=0(0 \%)$, "Less" frequency $=5(29.41 \%)$, "Medium" frequency = $10(58.82 \%)$, "Good" frequency $=2$ $(11.76 \%)$, "Good One" frequency $=0(0 \%)$. Then, according to the data collected from 19 sample representing the female student, then obtained a spread of answers based on the level of classification as follows, classified as "Very Good" frequency $=0 \%$, "Good" frequemcy $=4(21: 05 \%)$, "Medium" frequency = $12(63.16 \%)$, "Less" frequency $=3$ (15.79\%)

From the above, it can mean that students who have a good level of physical fitness course, students who are accustomed to physical activity, such as sports games such as playing football, chase, run, jump. From their habit for a long play to enrich the components of physical fitness of the child. In the play they will be running, jumping, throwing. It can be concluded students who have good physical fitness is certainly capable and difficulty in performing a variety of activities provided by the teacher in teaching physical education .

Based on research results suggest that the level of physical fitness grade students of Class IV Elementary School 44 Kalumbuk Padang rated "Medium" it can be concluded that the components of physical fitness is important in physical activity of students Class IV Elementary School 44 Kalumbuk Padang in improving physical fitness, then efforts can be done to improve the physical fitness of students are: 1) Teachers of physical education sport and health to pay attention again on factors of physical activity of children in the learning process, as well as provide knowledge about the importance of physical fitness, 2) Principal in order to augment and complement the learning infrastructure of sports physical education and health,3) The students to be more active physical activity in order to achieve physical fitness better and pay attention to food intake, 4) Parents, give direction to the child to live a regular, healthy and doing sports activities to improve physical fitness and attention to the nutritional needs of their children,

\section{CONCLUSION}

1. Physical Freshness Son of Class IV students of SD Negeri 44 Kaluambuk Padang are at moderate categorized klafikasi Enough

2. Physical Freshness Fourth Grade Elementary School Students 44 Kaluambuk Padang arriving at moderate categorized klafikasi Enough.

3. Physical Freshness Students son and daughter Elementary School Fourth Grade 44 Kaluambuk Padang are at moderate categorized klafikasi Enough.

\section{REFERENCES}

[1] Agus, A. Maitera. "Theory and Practice Management Center". Padang. 2013.pp.54-75. 
[2] R. Sepriani, \& E. Eldawaty. "Physical Fitness Mother Mother In jorong Kp. Alai Nagari tuft SUB Lubuk Sikaping Pasaman". J. Menssana, Vol. 3 No. 2,pp 47-52. November 2018.

[3] S. Sepriadi, S.Hardiansyah, \& H. Syampurma. "Physical Freshness Rate Differentials Based on Nutritional Status". J. Media Ilmu Keolahragaan Indonesia, Vol. 7 No. 1, 24-34. Juni. 2017
[4] S. Hardiansyah. "Ability Analysis Conditions of Students Faculty of Sport Science State University Padang". J. Menssana Vol. 3 No 1,pp. 117-123. May 2018.

[5] Arsil. "Evaluation of Physical Education and Sport". Malang: Wineka Media. 2015. pp.40-54. 